\title{
Prematüre Bebeklerde Tamamlayıcı Beslenme
}

\section{Complementary Feeding in Preterm Infants}

\author{
Sinem Yalnızoğlu Çaka ${ }^{1}$ (iD) Faruk Kabul ${ }^{2}$ (D) Nursan Çınar ${ }^{1}$ \\ ${ }^{1}$ Sakarya Üniversitesi Sağlık Bilimleri Fakültesi Hemşirelik Bölümü Çocuk Sağlığı ve Hastalıkları Hemşireliği Anabilim Dalı, Sakarya, TÜRKIYE \\ ${ }^{2}$ Sakarya Üniversitesi Sağlık Bilimleri Enstitüsü, Hemşirelik Anabilim Dalı, Sakarya, TÜRKIYYE
}

Gelis tarihi/ Date of receipt: 15/02/2021 Kabul tarihi/ Date of acceptance: 06/04/2021

(C) Ordu University Faculty of Health Sciences, Department of Nursing, Turkey, Published online: 18/04/2021

\section{ÖZ}

Gebelikten itibaren ele alındığında yaşamın ikinci yılına kadar olan ilk 1000 günde optimum beslenme, hem çocukluk hem de yetişkinlik döneminde bireysel sağlık durumunu şekillendirmede önemli bir potansiyele sahiptir. Bebeklik döneminde doğru beslenme, ilk altı ay tek başına olmakla birlikte iki yıl ve ötesine kadar devam ettirilebilecek olan anne sütü ile miktarı ve besin değeri dikkate alınarak hazırlanan yeterli ve kaliteli tamamlayıcı beslenmedir. Literatürde prematüre bebeklerin (gestasyon yaşı <37 hafta) beslenmesinin uzun vadeli etkilerine olan ilgi artmasına rağmen, bu bebeklerde tamamlayıcı beslenmeye geçiş ile ilgili sınırlı bilimsel kaynak mevcuttur. Bu derlemenin amacı bilimsel bilgilere dayanarak prematüre bebeklerde tamamlayıcı beslenme konusundaki son gelişmeleri değerlendirmektir.

Anahtar kelimeler: Prematüre, yenidoğan, tamamlayıcı beslenme, hemşirelik

\begin{abstract}
When considered from pregnancy to the second year of life, optimum nutrition in the first 1000 days has an important potential in shaping individual health status in both childhood and adulthood. Proper nutrition in infancy is feeding with breast milk that to be given alone for the first six months and can be continued for up to two years or beyond, together with adequate and high-quality complementary nutrition, considering its quantity and nutritional value. Despite the increased interest in the long-term effects of feeding premature babies (gestational age <37 weeks) in the literature, there are limited scientific resources regarding the transition to complementary feeding in these babies. The purpose of this review is to evaluate the latest developments in complementary nutrition in premature babies based on scientific knowledge.
\end{abstract}

Key words: Premature, newborn, complementary feeding, nursing

ORCID IDs of the authors: SYÇ: 0000-0002-1572-7013, FK: 0000-0003-1187-3133, NÇ: 0000-0003-3151-9975

Sorumlu yazar/Corresponding author: Arş. Gör. Dr. Sinem Yalnızoğlu Çaka

Sakarya Üniversitesi Sağlık Bilimleri Fakültesi Hemşirelik Bölümü Çocuk Sağlı̆̆ı ve Hastalıkları Hemşireliği Anabilim Dalı, Sakarya, TÜRKIYE e-posta/e-mail: sinemyalnizoglu@ sakarya.edu.tr

Atıf/Citation: Yalnızoğlu Çaka S, Kabul F, Çınar N. (2021). Prematüre bebeklerde tamamlayıcı beslenme. Ordu Üniversitesi Hemşirelik Çalışmaları Dergisi,4(1), 133-140. DOI:10.38108/ouhcd.880341 


\section{Giriş}

Günümüzde sağlık alanında gelişen teknoloji ile birlikte preterm doğumların yaygınl $\breve{g ̆}_{1}$ ve bu yenidoğanların hayatta kalma olasılığı artmaktadır. Her yıl tahminen 15 milyon bebek zamanından erken doğmaktadır, bu da Türkiye'de dahil 184 ülkede doğan bebeklerin \%5-18'ini temsil etmektedir (WHO, 2018). Preterm doğum yenidoğanın bilişsel, motor, dil, davranışsal, sosyal ve emosyonel gelişimini etkileyebilmektedir (Palazzi ve ark., 2017). Bununla birlikte ne yazık ki, bu yenidoğanların özellikle beslenme, büyüme ve gelişme ile ilişkili morbidite oranları zamanında doğan bebeklere oranla daha fazla vardır (Pagliaro ve ark., 2016). Yetişkinlerde kronik bulaşıcı olmayan hastalıklar için artan riskler (obezite, periferik insülin direnci, Tip II diyabet, hipertansiyon ve kardiyovasküler hastalık vb.), metabolik programlama üzerindeki etkilerin aracılık ettiği erken doğumlarda yetersiz büyüme ile ilişkilendirilmektedir (de Cardoso-Demartini ve ark., 2011; Kerkhof ve ark., 2012). Yukarıda belirtilen hastalıklar için risk faktörleri arasında aşırı kalori ve protein tedariği ile tamamlayıc1 beslenmeye (TB) erken başlatılması da yer almaktadır (Kerkhof ve ark., 2012; Vissers ve ark., 2018). Bu aşamada doğum sonrası büyüme ve gelişmenin doğrudan gıdanın miktarı ve kalitesiyle ilişkili olduğunu vurgulamak önemlidir.

Prematüre bebeklerin beslenmesinin uzun vadeli etkilerine olan bilimsel ilginin sürekli artmasına rağmen, bugüne kadar Dünya Sağlık Örgütü tarafindan (2002) "anne sütünün artık bebeklerin beslenme gereksinimlerini karşılamaya yetmediği ve böylece anne sütü ile birlikte başka yiyecek ve sıvılara ihtiyaç duyulduğu zaman başlayan süreç" olarak da bilinen tamamlayıcı beslenmeye çok az ilgi gösterilmektedir. Ayrıca erken doğmuş bebeklerde TB ile ilgili bir k1lavuz yoktur ve hem Avrupa Pediatrik Gastroenteroloji, Hepatoloji ve Beslenme Derneği (ESPGHAN) hem de İtalyan Pediatri Derneği tarafından yayınlanan son öneriler, özellikle katı gıdaların sağlıklı term bebeklere tanıtılmasına rehberlik etmeyi amaçlamaktadır (Alvisi ve ark., 2015; Fewtrell ve ark., 2017). Bu nedenle, sağlık profesyonellerinin erken doğmuş bebeklerde TB'ye yönelik tutumu hem ülkeler içinde hem de ülkeler arasında son derece değişkendir. Konu ile ilgili İtalyan Pediatri Derneği tarafindan desteklenen ve birinci basamak pediatristler arasında yürütülen yakın tarihli bir çalışmada, TB'ye başlamanın zamanlamasında ve TB'ye başlamak için önerilen gıda türlerinde geniş bir değişkenlik olduğu belirtilmektedir (Baldassarre ve ark., 2018).

\section{Prematüre Bebeklerde Tamamlayıcı Beslenmeye Başlama Zamanı}

Beslenme; sağlığın korunması, yaşamın sürdürülmesi, büyüme ve gelişme için besinlerin kullanılmasıdır. Sağlıklı beslenme alışkanlığının yaşam biçimine dönüşmesi ve bu bilincin oluşması bebeklik döneminde gerçekleştirilen beslenme davranışları ile yakından ilişkilidir (Pekcan ve ark., 2015). Yaşamın temellerinin atıldığ 1 kritik bir dönem olan bebeklik döneminde beslenme uygulamaları, ileriki dönemlerde karşılaşılabilecek beslenme ile ilişkili sorunların ve hastalıkların önlenmesine katkı sağlar. Doğumdan başlayarak özellikle iki yaşa kadar geçen süreç, bebeğin sağlıklı gelişimi desteklemek adına insan yaşamının en önemli zaman dilimlerindendir (Gümüştakım ve ark., 2017; Lin ve ark., 2019). Tamamlayıc1 beslenme, bebeklerin kademeli olarak aile yemeklerini yemeye geçiş yaptığı dönem olarak tanımlanır. Bebeklik döneminde tamamlayıcı beslenmenin zamanında başlatılması, hem beslenme hem de gelişimsel nedenlerden dolayı gereklidir. ESPGHAN, tamamlayıcı beslenmeye en erken 17. haftada başlanmasını en geç 26. haftaya kadar ertelenmesini ve 6 aya kadar tek başına veya tam emzirmenin istenen bir hedef olduğunu bildirmektedir (Agostoni ve ark., 2008). Ancak zamanından erken doğan bebekler için bu tür kılavuzlar veya talimatların eksik olduğu görülmektedir. Ayrıca term yenidoğanlar için TB'de istenilen başlama zamanı 6 aylıkken prematüre bebeklere TB'ye başlama önerisinin çıkarımını yapmak, iki ana soruya bağlıdır: Birincisi, prematüre bir bebekte 6 ay neyi ifade eder (kronolojik/doğum sonrası yaş mı yoksa düzeltilmiş yaş mı)? İkinci olarak, 6 ayın düzeltilmiş yaşı ifade ettiğini varsayarsak, bu bebekler term yenidoğanlardan daha erken tamamlayıc1 beslenmeye başlamamalı mıdır (düzeltilmiş 6 aylık yaş yerine 4 aylık düzeltilmiş yaşta)?

Kat1 yiyeceklerin term yenidoğanlara tanıtılmasına ilişkin mevcut kılavuzlar, doğrudan prematüre doğan bebekler için kullanılmamalıdır. Ayrıca literatür incelendiğinde, verilecek en uygun yaş, yiyecek türü ve bu önemli diyet değişikliği döneminin daha sonraki sağlığı ve gelişimi etkileyip etkilemediğiyle ilgili sınırlı araştırma yapıldığ görülmektedir (Palmer ve Makrides, 2012).

Prematüre bebeklerde TB'ye geçişte düzeltilmiş yaş ve gelişimsel özellikleri dikkate alınır. Prematüre bebeğin yaşı 40 haftalık olana kadar 
postkonsepsiyonel yaş olarak ifade edilir ve düzeltilmiş yaş kavramı postkonsopsiyonel 40. hafta esas alınarak ele alınmalıdır. Örneğin 32. gebelik haftasında doğan ve postnatal 25 haftalık olan bir bebeğin düzeltilmiş yaşı; postkonsepsiyonel yaş $(32+25=57$ hafta $)-40$ hafta $=17$ haftadır (Acunaş ve ark., 2018). İyi bir baş kontrolünün geliştirilmesi, katı yiyeceklerin güvenli bir şekilde geçişte önemli bir kriterdir. Prematüre bebeklerin, prematüre yaş için düzeltme yapıldıktan sonra bile, zamanında doğan bebeklere kıyasla erken kaba motor gelişimlerinin geciktiği gözlenmektedir (Van Haastert ve ark., 2006). Bebek beslenmesinde, ebeveynlere genellikle, dil itme (ekstrüzyon) refleksinin azaldığı, bebeğin destekle oturabilir pozisyonda durabildiği, başını dik tutabildiği ve ağzını açıp kaşığa doğru eğilebildiği zamanın gelişimsel olarak katı beslenmeye hazır olduğunun göstergeleri olduğu söylenmektedir (Barachetti ve ark., 2017). Bu nedenle hem düzeltilmiş yaş hem de gelişimsel hazırlık, katı gıdaya başlamadan önce dikkatle değerlendirilmesi gereken önemli faktörlerdir.

Literatürde mevcut çalışmalar, prematürelerin term bebeklere kıyasla katı gidalara daha erken başlama olasılığının önemli ölçüde daha yüksek olduğunu göstermektedir. Polonya ve Avusturya'da gerçekleştirilen bir kesitsel araştırmada, preterm bebeklerin Avusturya'da neredeyse \% 60'ının, Polonya'da ise \% 80'inin dört aylıktan önce TB'ye başladığ1 ve erken doğumun katı gıdalara erken başlama riskinde, zamanında doğuma kıyasla dört ile on kat artışa neden olduğunu saptamışlardır (Zielinska ve ark., 2019). Yapılan çalışmalarda diğer önemli bir konu da dikkati çekmektedir. Prematüre bebeklerin düzeltilmiş yaşları hesaba katıldığında bile, zamanında doğmuş bebeklerden daha erken TB'ye geçtikleri saptanmıştır. Norris ve arkadaşlarının (2002) yaptığı çalışmada, dahil edilen erken doğmuş bebeklerin \%95'inin çok erken (ortalama düzeltilmiş yaş 11.5 hafta) tamamlayıcı beslenmeye geçtikleri saptanmıştır. Benzer şekilde, Avustralya'da yapılan yakın tarihli bir çalışma, pretermlerin (ortalama düzeltilmiş yaş 14 hafta), term bebeklere (ortalama yaş 19 hafta), kıyasla çok daha erken katı gıdalara geçiş yaptığını göstermektedir (Cleary ve ark., 2020). Bu konuda yapılan diğer bir sistematik derlemede de erken doğmuş bebeklerin düzeltilmiş yaşları dikkate alındığında 11.5 - 15.1 hafta arasında tamamlayıcı beslenmeye başladığını vurgulamaktadır (Vissers ve ark., 2018). Konu ile ilgili ülkemizde mevcut bir çalışmaya rastlanmamakla birlikte, Usta ve arkadaşlarının (2020) preterm doğan çocuklarda 36. ay persentil eğrilerini değerlendirdikleri araştırmalarında, çalışmaya katılan bebeklerin $\% 57.8$ 'inin 6 aydan daha az süre sadece anne sütü aldığ1 ve \%81.3'ünün 18 aydan daha az süre anne sütü aldığı vurgulanmaktadır. Ancak çalışmada kronolojik/doğum sonrası yaş mı yoksa düzeltilmiş yaş $\mathrm{m}$ dikkate alındığı belirtilmemiştir.

İtalya'da 2000'li yılların başında gerçekleştirilen bir araştırmada elde edilen bulgular, prematüre bebeklerin \%60'ından fazlasının düzeltilmiş yaş dikkate alındığında dördüncü ayından önce tamamlayıcı beslenmeye geçtiğini göstermektedir. Ayrıca birçoğunda tercih edilen ilk gıdanın enerji ve protein içeriğinin düşük olması nedeniyle beslenme açısından yetersiz kaldığ 1 görülmüştür (Fanaro ve ark., 2007). Benzer şekilde Amerika Birleşik Devletleri'nde yapılan diğer bir çalışmada prematüre bebeklerin neredeyse yarısının düzeltilmiş beklenen yaştan önce bir miktar katı yiyecek aldığını ve bu durumun bebeklerin uzunluğunda benzer bir artış olmaksızın kilo alımında hızlı bir artışa neden olduğunu göstermektedir (Rodriguez ve ark., 2018). Prematüreliğin derecesi, TB'nin zamanlamasında önemli bir belirleyicidir. Braid ve arkadaşları tarafından yapılan çalışmada (2015), zamanında doğan bebeklere kıyasla, 22-32 hafta arasında doğan prematürelerin, dördüncü ayından önce kat1 yiyecekler ile beslenme olasılığının daha yüksek olduğu belirtilmiştir.

İtalya'da hekimler üzerinde gerçekleştirilen bir çalışmada (2018), tamamlayıcı gıda türlerinin kanıta dayalı bir sıraya uymadığı vurgulanmaktadır. Çocuk doktorlarmin \%98'inin D vitamini ve \%89'unun demir takviyesinin zamanlamasında ve dozlarında farklı uygulamalar sergiledikleri görülmektedir (Baldassarre ve ark., 2018). Gerçekleştirilen bir diğer çalışmada ise (2018) geç preterm (gestasyon haftas1 ortalamas1 34-36 hafta) bebeklerin de kat1 gidalara önerilenden daha erken, ortalama doğum sonrası 5.7 aylık ve ortalama düzeltilmiş yaş 4.6 aylık olduklarında verildiğini göstermektedir (Giannì ve ark., 2018). Bu çalışma, özellikle, meyvenin ilk katı gıda türü olarak tanıtılmasının tamamlayıc beslenmeye olması gerekenden 1.4 ay önce başlayanlarda daha sik olduğunu da göstermiştir.

Tamamlayıc1 beslenmeye geçişte farklı zamanlamaları değerlendiren deneysel çalışmalar son derece sinırlidir. Marriott ve ark. tarafindan (2003) gerçekleştirilen çalışmada, erken tamamlayıcı beslenmeye geçen gruptaki prematüre 
bebeklerin, en az $3.5 \mathrm{~kg}$ vücut ağırlığına ulaşmaları koşuluyla, 13 haftalık olduklarında yarı katı yiyecek almaları sağlanmıştır. Ayrıca bu gruptaki yenidoğanların ebeveynlerine enerji ve protein açısından yüksek yiyecekleri kullanmaları, kurutulmuş tahılları ve evde hazırlanan yiyecekleri prematüre mamasıyla karıştırmaları önerilmiştir. Kontrol grubundaki bebeklere ise en az $5 \mathrm{~kg}$ ağırlıkta olmaları koşuluyla 17 haftalıkken TB başlanmış ve gıda kalitesi için özel bir tavsiye verilmemiştir. On iki aylıkken, TB'ye erken başlayan bebekler kontrol grubundakilere kıyasla daha uzun boylu oldukları, ağırlık veya baş çevresinde ise farklılık olmadığı saptanmıştır. Bununla birlikte, boy uzunluğunun sadece erken bir TB'ye mi yoksa erken TB ile besin enerjisi ve protein içeriği konusundaki önerilerin bir kombinasyonuna $\mathrm{m}$ bağlanabileceği açık değildir. Ayrıca çalışmanın sonuçları, yalnızca zamanlamaya değil, aynı zamanda sunulan katı yiyeceklerin kalitesine de dikkat çekmek gerektiğini bildirmektedir. Hindistan'da gerçekleştirilen bir diğer çalışmada (2017), gestasyon yaşı <34 hafta olan bebeklerde iki farklı TB zamanlaması karşılaştırılmıştır. Tamamlayıcı beslenmeyi 4. veya 6. ayda alan prematüre bebekler arasinda 12 aylık düzeltilmiş yaşa göre $\mathrm{Z}$ skorlarında (yaşa göre kilo) anlamlı bir fark saptanmazken, düzeltilmiş yaşa göre dört aylık TB'ye başlayan preterm bebekler, altı aylık başlayanlara göre daha s1k hastaneye yatmaya ihtiyaç duydukları vurgulanmıştır (Gupta ve ark., 2017).

Prematüre bebeklerde TB'nin erken uygulanmasına yönelik eğilim, bu konuda ebeveynlere kısa ve uzun vadeli sağlık üzerindeki potansiyel sonuçlarına ilişkin verilen uygun beslenme eğitiminin olmaması ile de ilişkilendirilebilir. Konu ile ilgili gerçekleştirilen bir Cochrane incelemesinde (2019), aile bireylerine TB ile ilgili eğitimin prematüre bebeklerin büyümesine ve gelişimine etkisi araştırılmış ancak, uygun bir çalışma bulunamamıştır (Elfzzani ve ark., 2019). Bu sonuçlar da prematüre bebekler için ideal bir TB stratejisinin belirlenmesinde kanitların yetersiz oluşunu destekler niteliktedir.

Tamamlayıcı Beslenmede Kullanılacak Besin

\section{Kalitesi ve Klinik Sonuçları}

Prematüre doğan bebeklerin özellikle enerji, protein, uzun zincirli çoklu doymamış yağ asitleri, demir, çinko, kalsiyum ve selenyum için beslenme gereksinimleri vardır (Fuller ve ark., 1992; Loui ve ark., 2008; Berglund ve ark., 2010; Hay ve Thureen, 2010). Erken doğumun bir sonucu olarak, bu bebekler genellikle sinırlı besin depolarına sahiptirler, çünkü fetüse aktif besin aktarımının, birikimin ve hızlı bir büyümenin gerçekleştiği gebeliğin son üç aylık dönemini kaçırmışlardır. Gebeliğin son üç aylık döneminde, organ olgunlaşması ve gelişmesinin yanı sıra önemli fetal büyüme de vardır. Prematüre bebeklerin yüksek besin ihtiyaçlarının yanı sıra organların henüz tam olarak olgunlaşmamış olması, prematüre bebeklerin in utero büyüme hızına ulaşmasını sağlayacak diyet alımını daha da zorlaştırır.

İlk altı ayda anne sütü ile beslenen bebeğin ayına göre verilecek yeni besinlerin miktarı, içeriği ve cinsi ileri yaşlarda oluşabilecek diyabet şişmanlık ve hipertansiyon gibi hastalıklara zemin hazırlayabileceği gibi benzer hastalıklardan korunmada da önemli bir rol oynayabilir (Selimoğlu, 2014). Prematüre bebeklerin term yenidoğanlara göre enerji gereksinimlerinin daha yüksek olduğu bilinmektedir ve tek başına anne sütü veya bebek sütlerinin (formüla mama) ne kadar süreyle ihtiyaçlarını karşılamak için yeterli olduğu tam olarak bilinmemektedir (Bauer ve ark., 2009; Weintraub ve ark., 2009). Çoğu tamamlayıcı gıda, anne sütü ve türevlerine kıyasla daha yüksek kalori yoğunluğu sağlar ve prematüre bebeklerin artan gereksinimlerini karşılayabilir. Enerji gereksinimi ayrıca prematürenin doğum haftasındaki gestasyon yaşına göre de farkl11ık gösterir. Embleton ve arkadaşlarının yaptıkları bir çalışmada (2017) erken doğmuş bebeklerde (gebelik $<34$ hafta) ilk hastaneye yatışa oranla 7 günlük olduklarında, enerji ( 400 kcal / kg) ve proteinde (13 g/ kg) kayıp yaşadıklarını belirtmişlerdir ve bebeğin immatüritesinin enerji gereksinimini arttıracağını vurgulamışlardır. Diyetle alım aynı zamanda büyümeyi "yakalama" ihtiyacını da karşılamalıdır; beslenme ve büyüme arasındaki ilişki veya yetersiz beslenmeye bağlı büyümedeki gecikmeler literatürde de kanıtlanmıştır (Salvatori ve Martini, 2020). Bu nedenle, TB'ye başlama zamanı ve klinik sonuçlarını değerlendirmek son derece önemlidir. Mevcut literatür incelendiğinde sinırlı sayıda araştırmanın, TB'ye başlama zamanının preterm bebeklerin sağlığı üzerine uzun ve kısa vadeli etkilerini araştırdığı görülmektedir.

Prematüre bebeklerin büyüme ve gelişmesi ile ilgili İngiltere'de 90'ların ortalarında yapılan ve 1600 'den fazla term ve prematüre bebekleri içeren çalışmada, kronolojik yaşın 12. haftasında tamamlayıcı beslenmeye başlamanın erken kilo alımını artırabileceğini göstermektedir. Ancak bu durum uzun vadeli büyüme ile ilişkilendirildiğinde, 
bu yaştan önce veya sonra TB alan bebekler arasında önemli ölçüde farklı görünmemektedir (Morgan ve ark., 2004). Benzer şekilde, Spiegler ve arkadaşları tarafindan (2015) Almanya'da yaklaşı 1000 preterm bebekte retrospektif olarak gerçekleştirilen çalışmada erken zamanda katı gıda verilmesinin iki yaşındaki boy ve kilo üzerindeki olumsuz etkisini bildirmemişlerdir. Mevcut bilgiler dikkate alındığında, TB'ye geçiş zamanlamasındaki varyasyonların, erken doğmuş bebeklerde obezite veya aşırı kilodaki artışla iliş̧kili olup olamayacağını açıklığa kavuşturmak için yetersiz kaynak olduğu söylenebilir. Ancak, term yenidoğanlarda, katı yiyeceklerin dört aylıktan önce veya alt1-yedi aydan sonra sunulmasının, daha yüksek şişmanlık, artmış aşırı kilo ve çocukluk obezitesi riski ile ilişkili olabildiği de dikkate alınmalıdır (Papoutsou ve ark., 2018; Gingras ve ark., 2019).

Mevcut literatürdeki yetersizlik göz önüne alındığında, şu anda prematüre bebeklerde büyüme ve yaşamın sonraki yıllarındaki sağlık sorunları ile ilgili olarak TB'nin optimal zamanlaması hakkında bir öneri yapılamayacağı düşünülmektedir. Bununla birlikte TB'ye en erken dördüncü ayda başlatılması gerekliliği gastrointestinal sistemin olgunlaşması, nörolojik gelişim ve besinsel gereksinim gibi bazı fizyolojik ihtiyaçlara dayandırılmaktadır. Altıncı aydan sonraya bırakılması; yetersiz enerji alımına, demir eksikliğine, oral motor fonksiyonlarda gecikmeye ve gida reddi gibi problemlere yol açabilmektedir (Selimoğlu, 2014).

\section{Tamamlayıcı Beslenme ile İlgili Güncel Öneriler}

Şu anda prematüre bebeklerde TB'ye geçişe ilişkin herhangi bir kılavuz mevcut olmasa da, prematüre bebekler için katı gida verilmesine ilişkin tavsiye ve önerileri içeren, Birleşik Krallık Sağlık Bakanlığı'nın 1994 yılında yayınlanan "Committee on Medical Aspects of Food and Nutrition" (COMA, 1994) raporudur. COMA raporuna göre, preterm bebek $5 \mathrm{~kg}$ ağırlığına ulaşmakla birlikte dil itme (ekstrüzyon) refleksi azalmış ve kaşıktan yemek yiyebilme gibi birkaç gelişimsel özellikler kazandıktan sonra katı gıdalara başlanabileceğini önermektedir.

Bununla birlikte, COMA raporunda yapilan önerilerin, günümüzde erken doğmuş bebekler için yetersiz kalacağı düşünülmektedir. Prematüre bebeklerde TB'ye başlamak için bir ağırlık sınırı seçimi muhtemelen yanıltıcıdır, çünkü en erken doğan ve yavaş büyüyen bebekler ESPGHAN tarafindan önerilen term bebeklerde TB'ye optimal geçiş penceresinin (4-6 aylık) çok ötesinde 5 kg'a ulaşacaktır. Ek olarak, TB'ye başlamadan önce ulaşılacak seçilmiş bazı gelişimsel beceriler, prematürelerde bebekten bebeğe değişim gösterebilir ve bu nedenle potansiyel olarak daha fazla gecikmeye yol açabilir.

$\mathrm{Bu}$ nedenle COMA raporunda önerilen sinırlamaları esnetmek için, erken doğmus bebeklerde düzeltilmemiş beş ile sekiz aylık belirli bir zamansal pencere içinde TB'ye başlanması önerilmiştir (King, 2009). Böyle bir pencere seçimi, genel olarak bebeğin oral motor gelişimi, zevk alma ve yeni dokuları keşfetmeye hazır olma dahil olmak üzere birçok davranışsal ve gelişimsel durumlarını kazanması için bir olanak sağlar. Aslında, beş ile sekiz ay arasında hemen hemen tüm prematüre bebekler, dil itme refleksinin giderek kaybolmas1, refleksif emmenin azalması gibi süt dışındaki yiyeceklerin tüketimine izin veren gelişim becerilerini edinmiş olmalıdır. Ek olarak, bu zaman penceresi, prematüre bebeklerde erken doğumdan nasıl etkilendiği bilinmese bile, yeni tatlar ve dokular tanıtmak için term bebeklerde aslında en uygun olan zamandır (King, 2009; Palmer ve Makrides, 2012). Konu ile ilgili yapılan bir çalışmada, erken doğmuş ve zamanında doğmuş bebeklerin katı yiyeceklerle ilk temasta olan duygusal tepkilerini karşılaştırılmış ve çalışma yazarlarının beklentilerinin aksine, erken doğmuş bebekler yeni yiyeceklere tepki olarak daha az olumsuz duygu gösterdikleri ve katı gıdaya hızla uyum sağladıkları, yeni gıdalara tekrar tekrar maruz kaldıktan sonra negatif yüz ifadelerinin sıklığ azaldığı da görülmüştür (Longfier ve ark., 2016).

Katı gıdaya güvenli ve başarılı bir geçişte, düzeltilmiş yaşa göre üç aydan (13 hafta) önce başlanmasının önerilmemesinin nedeni prematüre bebeklerin kaba ve ince motor gelişimlerinin yetersiz olmasindan kaynaklanmaktadır. $\mathrm{Bu}$ nedenle, erken doğmuş bebeklerde TB'ye başlamak için en uygun zamanlamanın değerlendirilmesinde düzeltilmiş yaşın da dikkate alınması önerilebilir. Çünkü bu aynı zamanda, hem aşırı hem de geç preterm bebekler göz önüne alındığında prematüre bebeklerin heterojenliği için birleştirici bir kriter oluşturacaktır (Liotto ve ark., 2020). Ancak bu konuyla ilgili yayınlanan bir rehberde, ileri düzeyde prematüre doğan bebeklerin, 5 kg'a ulaşmadan önce 10 aylık düzeltilmemiş yaşta olabilecekleri ve bu nedenle anne sütü dışında ağızdan verilen herhangi bir besine karşı dirençli olabilecekleri de vurgulanmaktadır (King, 2009).

$\mathrm{Bu}$ sorunlar dikkate alındığında, prematüre bebeğin en az 3 aylık düzeltilmiş yaşta olması 
koşuluyla, kaba motor gelişiminin güvenli beslenmeyi sağlaması yeterli olduğu da göz önüne alınırsa, 5 ile 8 aylık düzeltilmemiş yaş arasında katı gıdaya hazır olabileceği önerilebilir. Mevcut sınırlı kanıtlara dayanarak, 3 aylık (13 haftalık) düzeltilmiş bir yaşın, çoğu erken doğmuş bebek için katı gıda verilmesini başlatmak için uygun bir yaş olabileceği sonucuna varılabilir. Bu durumda örneğin 23. gebelik haftasında doğan prematürelerin yedi aylık düzeltilmemiş bir yaşı olurken, 36. gebelik haftasına yakın doğan bebeklerin 4 aylık düzeltilmemiş bir yaşı olacaktır. Böylece düzeltilmemiş yaşı kullanarak, preterm spektrumunun her iki ucu, gelişimsel açıdan ideal dönemde katı yiyecekler tüketiyor olacaktır. Ayrıca yapılan bir çalışmada düzeltilmiş 3 aylık (13 haftalık) yaştan itibaren katı gida verilmesinin potansiyel olarak egzama gelişimi riskini de azaltacağı bildirilmektedir (Morgan ve ark., 2004b).

Konu ile ilgili Marriott ve arkadaşlarının (2003) gerçekleştirdikleri çalışmada ise üç aylık düzeltilmiş yaşın çok geç olduğu vurgulanmaktadır. Bununla birlikte, doğumdan katı gida verilmesine kadar geçen sürede optimal besin alımının sağlanması beslenme durumunu iyileştirecektir. Yüksek proteinli, enerjili ve besleyici yiyeceklerin tercih edilmesi, kat1 yiyecekler başlandıktan sonra prematüre bebekler için önemlidir (Barachetti ve ark., 2017). Özellikle erken doğmuş bebeklerde kanıta dayalı k1lavuzlar oluşturabilmek için daha fazla araştırma yapılması gerekmektedir ve bu çalışmalarda, katı gıdanın türü ve zamanlamasının sağlık ve gelişimsel sonuçlarının hem kısa hem de uzun vadeli değerlendirilmesi amaçlanmalıdır.

\section{Sonuç}

Prematüre bebeklerde TB'ye geçiş ile ilgili;

- Konu ile ilgili yeterli bilimsel kaynak ve çalışma olmadığından kanıta dayalı öneriler yapılamamaktadır.

- Erken doğan bebeklerin çoğunluğunun doğum tarihinden itibaren 5-8 ay arasinda (düzeltilmemiş) TB'ye hazır olması muhtemeldir. Bununla birlikte, katı gidalara güvenli ve başarılı bir geçiş için gerekli olan motor gelişimin, düzeltilmiş yaş en az 3 aya kadar elde edilmemiş olabileceğine dair kanıtlar vardır. Kesin yaş, bir bebekten diğerine değișebilir, bu nedenle beslenme ipuçları ve fiziksel gelişim hakkında verilen tavsiyeler her bebeğe özel değerlendirilmelidir.
- $\quad$ TB'ye geçiște prematüre bebeğin sadece yașı değil aynı zamanda nöromotor gelişimi de önemlidir.

- Mevcut sonuçlar, gelişimsel kilometre taşları ve sözlü beceriler açısından son derece değişken bir popülasyon oluşturan tüm prematüre bebekler için güvenli bir şekilde TB'ye geçiş için kesin sınırları olan belirli bir zamanlama olmadığını göstermektedir. Bu nedenle, erken doğmuş bebeklerde TB'ye, düzeltilmiş veya doğum sonrası yaştan ziyade esas olarak bebeklerin gelişimine dayalı kişiselleştirilmiş bir değerlendirmeyi takiben başlanmasını öneriyoruz.

- Oral disfonksiyon ile doğan prematürelerde beslenme ve TB'ye geçiş, bu alanda uzman sağl1k profesyonelleri, beslenme uzmanları ve konuşma terapistlerini içeren multidisipliner bir ekip tarafindan yürütülen kişiselleştirilmiş bir girişime ihtiyaç duyacaktır.

- TB uygulamaları ile ilgili olarak kısa ve uzun vadede büyümeyi, büyüme kalitesini ve sağlığı değerlendirmeyi amaçlayan ileriye yönelik çalışmalar tavsiye edilebilir.

- Ayrıca sağlık açısından etkileri göz önüne alındığında, prematüre bebekler için özel kılavuzlar geliştirilmesi ve gelecekte, prematüre bebeklere erken veya geç TB'ye başlamanın yordayıcılarını inceleyen çalışmalar önerilir.

Araştırmanın Etik Yönü/ Ethics Committee Approval: Kaynaklar bölümünde kullanılan literatür gösterilmiștir.

Hakem/Peer-review: Dış hakem değerlendirmesi.

Yazar Katkısı/Author Contributions: Fikir/kavram: SYÇ, FK, NÇ; Tasarım: SYÇ, FK; Danışmanlık: NÇ; Veri toplama: SYÇ, FK; Analiz ve/veya Yorum: SYÇ, NÇ Kaynak tarama: SYÇ, FK; Makalenin Yazımı: SYÇ, FK; Eleştirel inceleme: NÇ.

Çıkar çatışması/Conflict of interest: Çalışmada herhangi bir çıkar çatışması söz konusu değildir.

Finansal Destek/Financial Disclosure: $\mathrm{Bu}$ çalışma herhangi bir kurum ya da kuruluş tarafından desteklenmemiştir.

Çalışma Literatüre Ne Kattı?

- Yaşamin erken dönemlerinde beslenme, prematüre bebeklerin klinik sonuçlarını hem kısa hem de uzun vadede etkileme potansiyeline sahiptir.

- Şu anda, tamamlayıcı beslenmenin preterm bebeklerin sağlığını şekillendirmedeki spesifik katkısının ne olduğu belirsizdir. 
- Bu derlemenin sonuçları, preterm olarak doğan bebeklerde katı gida verilmesinin optimal özelliklerine ilişkin verilerin yetersizliğini vurgulamaktadır.

\section{Kaynaklar}

Acunaş B, Uslu S, Baş AY. (2018). Türk Neonatoloji Derneği yüksek riskli bebek izlem rehberi. Türk Pediatri Arşivi, 53(Supp: 1), 180-195.

Agostoni C, Decsi T, Fewtrell M, Goulet O, Kolacek S, Koletzko B, ve ark. (2008). Complementary feeding: a commentary by the ESPGHAN Committee on Nutrition. Journal of Pediatric Gastroenterology and Nutrition, 46(1), 99-110.

Alvisi P, Brusa S, Alboresi S, Amarri S, Bottau P, Cavagni G, ve ark. (2015). Recommendations on complementary feeding for healthy, full-term infants Italian Journal of Pediatrics, 41(1), 1-9.

Baldassarre ME, Di Mauro A, Pedico A, Rizzo V, Capozza M, Meneghin F, ve erk. (2018). Weaning time in preterm infants: An audit of italian primary care paediatricians. Nutrients, 10(5), 616 (1-6).

Barachetti R, Villa E, Barbarini M. (2017). Weaning and complementary feeding in preterm infants: Management, timing and health outcome. La Pediatria Medica e Chirurgica, 39(181), 115-119.

Bauer J, Werner C, Gerss J. (2009). Metabolic rate analysis of healthy preterm and full-term infants during the first weeks of life. The American Journal of Clinical Nutrition, 90(6), 1517-1524.

Berglund S, Westrup B, Domellöf M. (2010). Iron supplements reduce the risk of iron deficiency anemia in marginally low birth weight infants. Pediatrics, 126(4), 874-883.

Braid S, Harvey EM, Bernstein J, Matoba N. (2015). Early introduction of complementary foods in preterm infants. Journal of Pediatric Gastroenterology and Nutrition, 60(6), 811-818.

Cleary J, Dalton SM, Harman A, Wright IM. (2020). Current practice in the introduction of solid foods for preterm infants. Public Health Nutrition, 23, 94-101.

de Cardoso-Demartini AA, Bagatin AC, Silva RPGVC, Boguszewski MCDS. (2011) Crescimento de crianças nascidas prematuras TT- Growth of preterm-born children. Arquivos Brasileiros de Endocrinologia \& Metabologia, 55(8), 534-540.

Elfzzani Z, Ojha S, Dorling J. (2019). Education of family members to support weaning to solids and nutrition in infants born preterm. Cochrane Database of Systematic Reviews, 2, CD012240.

Fanaro S, Borsari , Vigi V. (2007). Complementary feeding practices in preterm infants: an observational study in a cohort of Italian infants. Journal of Pediatric Gastroenterology and Nutrition, 45(Suppl. 3), 210214.
Fewtrell M, Bronsky J, Campoy C, Domellöf M, Embleton N, Fidler Mis N, ve ark. (2017). Complementary Feeding: A position paper by the European Society for Paediatric Gastroenterology, Hepatology, and Nutrition (ESPGHAN) Committee on Nutrition. Journal of Pediatric Gastroenterology and Nutrition, 64(1), 119-132.

Fuller NJ, Bates CJ, Evans PH, Lucas A. (1992). High folate intakes related to zinc status in preterm infants. European Journal of Pediatrics, 151(1), 51-53.

Giannì ML, Bezze E, Colombo L, Rossetti C, Pesent N., Roggero P, ve ark. (2018). Complementary feeding practices in a cohort of Italian late preterm infants. Nutrients, 10(12), 1861 (1-12).

Gingras V, Aris IM, Rifas-Shiman SL, Switkowski KM, Oken E, Hivert MF. (2019). Timing of complementary feeding introduction and adiposity throughout childhood. Pediatrics, 144(6), e20191320 (1-9).

Gupta S, Agarwal R, Aggarwal KC, Chellani H, Duggal A, Arya S, ve ark. (2017). Complementary feeding at 4 versus 6 months of age for preterm infants born at less than 34 weeks of gestation: a randomised, openlabel, multicentre trial. The Lancet Global Health, 5(5), 501-511.

Gümüştakım RS, Aksoy HD, Cebeci SE, Kanuncu S, Çakır L, Yavuz E. (2017). 0-2 yaş çocuklarda beslenme alışkanlıklarının değerlendirilmesi: Çok merkezli çalışma. Family Practice and Palliative Care, 2(1), 1-8.

Hay WW, Thureen P. (2010). Protein for preterm infants: how much is needed? How much is enough? How much is too much?. Pediatrics \& Neonatology, 51(4), 198-207.

Kerkhof GF, Willemsen RH, Leunissen RWJ, Breukhoven PE, Hokken-Koelega AC. (2012). Health profile of young adults born preterm: negative effects of rapid weight gain in early life. The Journal of Clinical Endocrinology \& Metabolism, 97(12), 4498-4506.

King C (2009). An evidence based guide to weaning preterm infants. Paediatrics and Child Health, 19(9), 405-414.

Lin W, Baluyot KR, Yao M, Yan J, Wang L, Li G, ve ark. (2019). Early-life nutrition and cognitive development: 1maging approaches. In Human Milk: Composition, Clinical Benefits and Future Opportunities, 90, 121135.

Liotto N, Cresi F, Beghetti I, Roggero P, Menis C, Corvaglia L, ve ark. (2020). Complementary feeding in preterm infants: A systematic review. Nutrients, 12(6), 1843.

Longfier L, Soussignan R, Reissland N, Leconte M, Marret S, Schaal B, ve ark. (2016). Emotional expressiveness of 5-6 month-old infants born very premature versus full-term at initial exposure to weaning foods. Appetite, 107, 494-500. 
Loui A, Raab A, Braetter P, Obladen M, De Braetter VN. (2008). Selenium status in term and preterm infants during the first months of life. European Journal of Clinical Nutrition, 62(3), 349-355.

Marriott LD, Foot KD, Bishop JA, Kimber AC, Morgan JB. (2003). Weaning preterm infants: a randomised controlled trial. Archives of Disease in ChildhoodFetal and Neonatal Edition, 88(4), 302-307.

Morgan J, Williams P, Norris F, Williams CM, Larkin M, Hampton S. (2004b). Eczema and early solid feeding in preterm infants. Archives of Disease in Childhood, 89(4), 309-314.

Morgan JB, Lucas A, Fewtrell, MS. (2004a). Does weaning influence growth and health up to 18 months? Archives of Disease in Childhood, 89(8), 728-733.

Norris FJ, Larkin MS, Williams CM, Hampton SM, Morgan JB. (2002). Factors affecting the introduction of complementary foods in the preterm infant. European Journal of Clinical Nutrition, 56(5), 448454.

Pagliaro CL, Bühler KEB, Ibidi SM, Limongi SCO. (2016). Dietary transition difficulties in preterm infants: critical literatüre review. The Journal of Pediatrics, 92(1), 7-14

Palazzi A, Meschini R, Piccinini CA. (2017). Music Therapy Intervention for the Mother-Preterm Infant Dyad: Evidence from a Case Study in a Brazilian NICU. Voices, 17(2), 1-18.

Palmer DJ, Makrides M. (2012). Introducing solid foods to preterm infants in developed countries. Annals of Nutrition and Metabolism, 60(Suppl. 2), 31-38.

Palmer DJ, Makrides M. (2012). Introducing solid foods to preterm infants in developed countries. Annals of Nutrition and Metabolism, 60(Suppl. 2), 31-38.

Papoutsou S, Savva SC, Hunsberger M, Jilani H, Michels N, Ahrens W, ve ark. (2018). Timing of solid food introduction and association with later childhood overweight and obesity: The IDEFICS study. Maternal \& Child Nutrition, 14(1), e12471 (1-8).

Pekcan AG, Şanlıer N, Baş M. (2015). Türkiye Beslenme Rehberi (TÜBER). T.C. Sağlık Bakanlığı. 2.Baskı. Yayın No: 1031, Ankara, s:89-96

Rodriguez J, Affuso O, Azuero , Downs, CA, TurnerHenson A, Rice M. (2018). Infant feeding practices and weight gain in toddlers born very preterm: A pilot study. Journal of Pediatric Nursing, 43, 29-35.

Salvatori G, Martini L. (2020). Complementary Feeding in the Preterm Infants: Summary of Available Macronutrient Intakes and Requirements. Nutrients, 12(12), 3696.

Selimoğlu, M.A. (2014). Tamamlayıcı beslenme. Selimoğlu MA editör. Sağlıkta ve Hastalıkta Çocuk Beslenmesi. İstanbul: Akademi Uluslararası Yayıncilık, s. 55-62.
Spiegler J, Eisemann N, Ehlers S, Orlikowsky T, Kannt O, Herting E, ve ark. (2015). Length and weight of very low birth weight infants in Germany at 2 years of age: does it matter at what age they start complementary food?. European Journal of Clinical Nutrition, 69(6), 662-667.

U.K. Department of Health. (1994). Weaning and the Weaning Diet. Report of the Working Group on the Weaning Diet of the Committee on Medical Aspects of Food Policy. Reports on Health and Social Subjects, $45,1-113$.

Usta O, Ardıç C, Telatar TG. (2020). Preterm doğan çocuklarda ikinci ve üçüncü yaşta obezite değerlendirilmesi. Ankara Medical Journal, 20(3), 567-577.

Van Haastert IC, de Vries LS, Helders PJ, Jongmans MJ. (2006). Early gross motor development of preterm infants according to the Alberta Infant Motor Scale. Journal of Pediatrics, 149(5), 617-22.

Vissers KM, Feskens EJM, Van Goudoever JB, Janse AJ. (2018) The timing of initiating complementary feeding in preterm infants and its effect on overweight: A systematic review. Annals of Nutrition and Metabolism, 72(4), 307-315.

Weintraub V, Mimouni FB, Dollberg S. (2009). Effect of birth weight and postnatal age upon resting energy expenditure in preterm infants. American Journal of Perinatology, 26(03), 173-177.

World Health Organization (WHO) (2003). Complementary feeding : report of the global consultation, and summary of guiding principles for complementary feeding of the breastfed child. World Health Organization. Erişim tarihi:14.02.2021, https://apps.who.int/iris/handle/10665/42739

World Health Organization (WHO) (2018) Preterm Birth. Erişim tarihi:14.02.2021, https://www.who.int/newsroom/fact-sheets/detail/preterm-birth

Zielinska MA, Rust P, Masztalerz-Kozubek D, Bichler J, Hamułka J. (2019). Factors influencing the age of complementary feeding - A cross-sectional study from two European countries. International Journal of Environmental Research and Public Health, 16(20), 3799 (1-18). 